\title{
SOUTH AFRICA'S NUCLEAR DIPLOMACY SINCE THE TERMINATION OF ITS NUCLEAR WEAPONS PROGRAMME
}

\author{
Jo-Ansie van Wyk \\ University of South Africa
}

\begin{abstract}
This article reports on an analysis of South Africa's nuclear diplomacy since the country terminated its nuclear weapons programme, and explains why it has not retracted on this position. Through the skilful use of strategies typically used by middle powers in their conduct of nuclear diplomacy as niche diplomacy, South Africa has succeeded in norm construction, identity formation, and securing a niche role for itself, which resulted in material and non-material advantages for post-apartheid and post-nuclear weapons South Africa.
\end{abstract}

\section{Introduction}

On 24 March 1993, President FW de Klerk announced the extent of South Africa's nuclear weapons programme. He revealed that South Africa produced six nuclear devices as part of the country's three-phased nuclear deterrent strategy approved by Prime Minister John Vorster in April 1977. ${ }^{1}$ De Klerk's announcement was preceded by the establishment of a committee to oversee the dismantling and destruction of South Africa's nuclear devices in 1989, the release of political prisoners such as Nelson Mandela and the unbanning of liberation movements in 1990. An immediate task of the South African government after the decision to terminate the nuclear weapons programme was to decommission several nuclear weapon facilities in preparation for inspections by the International Atomic Energy Agency (IAEA) whilst maintaining the safety and security of the country's nuclear weapons equipment and stocks of highly enriched uranium (HEU). More importantly, South Africa had to convince the international community of the sincerity of its

Scientia Militaria, South African Journal of Military Studies, Vol 42, $\mathrm{Nr} 1,2014$, pp. 80-101. doi : $10.5787 / 42-1-1082$ intentions regarding nuclear nonproliferation.

Apart from these developments, South Africa was also 
in the early phases of its political transition to democratic rule. Barely a month after De Klerk's announcement, 26 South African political parties established the Multi-Party Negotiating Forum, which subsequently adopted the constitutional principles that formed the foundation of the South African Interim Constitution and initiated the Transitional Executive Council (TEC) to prepare the country for its first inclusive democratic elections in April 1994. This resulted in the establishment of a Government of National Unity (GNU) under the leadership of President Nelson Mandela, the President of the African National Congress (ANC).

International isolation was one of the hallmarks of South Africa's pre1990 diplomacy whereas the country's post-1990 diplomacy signified a major departure in terms of focus, scope, intensity and diversity. Consequently, the country's nuclear diplomacy, defined below, was also transformed. Since 1990, South Africa has conducted its nuclear diplomacy by constructing certain norms and its identity in a particular way to serve its national and international interests, and in the process - as a norm entrepreneur - aligning itself with internationally settled norms and advancing new and/or nascent nuclear norms. Why, despite possessing enough enriched uranium, technology, skills and clients, does the country not reverse the decision to terminate the South African nuclear weapons programme? In response, it is contended that the following propositions offer some explanation. Firstly, South Africa has constructed its norms, identity, role and interests in such a way to increase its diplomatic influence, authority, non-material power and economic incentives. Secondly, South Africa has constructed a unique brand of niche diplomacy, involving a number of diplomatic practices, to gain material and non-material rewards such as status, prestige and trade opportunities.

Against the aforesaid, the purpose here is to address the transformation of South Africa's state identity and norm construction pertaining to the country's nuclear diplomacy as a departure from, for example, its nuclear deterrent strategy by applying constructivism as the preferred theoretical approach. This theoretical approach to South African diplomatic practice and international relations is significantly neglected in scholarship on these issues. The utility of constructivism lies in its focus on the role of ideas, identity and interests for a state in the conduct of such country's international relations and diplomacy. The utility of constructivism is further rooted in its focus on norms in international relations and diplomacy. In essence, constructivists argue that ideas and norms inform a state's identity, which, in turn, informs that state's interests. ${ }^{2}$ This results in a perpetual cyclical process where construction and re-construction 
follow upon one another. When applied to South Africa's post-1990 nuclear diplomacy, this cyclical process remains prevalent. South Africa's rhetorical adherence to the norms of non-proliferation, disarmament and the peaceful uses of nuclear energy - the normative foundation of the Non-Proliferation Treaty (NPT) - has been consistent and repetitive. Informed by these norms, as well as the norms espoused by the ANC-led government's domestic and foreign policies, South Africa constructed a state identity as a unique nuclear state, which, in compliance with international norms, has terminated its nuclear weapons programme, subscribes to export control regimes and strongly supports the inalienable right of all states to use nuclear energy for peaceful purposes. From this flowed another state identity, namely that of a good international citizen.

For analytical purposes, four case studies representative of South Africa's construction and conduct of nuclear diplomacy are presented. These are the nuclear non-proliferation export control regimes, the IAEA, the African Nuclear Weapon-Free Zone Treaty (Pelindaba Treaty), and the nuclear nonproliferation regime in terms of the Treaty on the Non-Proliferation of Nuclear Weapons (NPT). These case studies represent South Africa's approach to the practice of nuclear diplomacy in a multilateral context which, in some instances, is supplemented by bilateral diplomacy. These case studies have also remained on and dominated the global nuclear agenda since 1990. Moreover, these cases represent the most dynamic areas of South Africa's nuclear diplomacy since 1990.

\section{Nuclear diplomacy}

The possession of nuclear weapons awards states considerable power and influence. However, South Africa is one of few countries to have terminated its nuclear weapons programme - others being Argentina, Brazil, Libya, and Ukraine. Globally, concerns about the proliferation of nuclear weapons continue in the wake of the Cold War as nuclear-weapon states (NWS) and so-called 'threshold states' diverge on aspects of the NPT. South Africa has not been shielded from these developments and has had to adapt its nuclear diplomacy and domestic legislation to maintain and enhance the country's status as an advocate and supporter of nuclear non-proliferation. The country's nuclear diplomacy with Iran, Iraq, Pakistan and India has also raised some diplomatic concerns among the traditional NWS who questioned South Africa's nuclear intentions. 
Apart from including the dismantling of its nuclear weapons programme, the post-1990 period has been most dynamic in terms of South Africa's international relations and diplomacy. During this period, the country established numerous bilateral relations, acceded to the Treaty on the Non-Proliferation of Nuclear Weapons (NPT) in 1991, and joined or re-joined several nuclear-related organisations, including the IAEA, and nuclear export control regimes. Apart from adopting a human rights-based foreign policy, post-apartheid ANC-led South Africa reiterated that a "primary goal" of its foreign policy is to "reinforce and promote South Africa as a responsible producer, possessor and trader of defence-related products and advanced technologies in the nuclear, biological, chemical and missile fields". 3 The government's argument was that South Africa, in this way, "promotes the benefits which non-proliferation, disarmament and arms control hold for international peace and security, particularly to countries in Africa and the Non-Aligned Movement". 4

The implications of the practice of nuclear diplomacy are wide-ranging:

- it illustrates the existence of a particular type of diplomacy to determine and apply internationally agreed safeguards and principles of verification of states' nuclear facilities and intentions;

- $\quad$ it entails the safety and security of nuclear material and scientists; and

- it entails the enforcement of settled norms relating to the development and application of nuclear science and technology for peaceful purposes.

Nuclear diplomacy is defined as the interaction among and between international actors (be they states, international organisations, individuals and transnational non-state organisations) on nuclear-related issues, actors and interests (be they material or non-material) to achieve objectives aligned with an actor's construction of its self- or national interests, its particular identity and the nuclear-related norms it initiates, innovates, maintains, and with which it is compliant or non-compliant. ${ }^{5}$

Predominantly, but not exclusively associated with middle powers, 'niche diplomacy' refers to a specific brand of diplomacy characterised by a high level of expertise and speciality which aims to utilise the diplomatic, scientific and technical expertise of a state to advance that state's national interests. ${ }^{6}$ This enables a state to focus its resources on specific issues where its diplomatic return is estimated to be the highest. Therefore, constructivists' claim that a state's power derives from non-material rather than material resources is aligned with the conduct of niche diplomacy. Due to their lack of abundant 
material resources to strengthen themselves as superpowers, middle powers typically specialise in one or more diplomatic fields in which they have often achieved significant successes.

South Africa's nuclear diplomacy has not only created a practical reality (no more nuclear weapons), but also a normative reality by bestowing upon the country a position and a role as a state that has relinquished its weapons programme to secure and maintain, as a norm entrepreneur (i.e. a state that initiates and/or promotes certain universally accepted norms of state behaviour), ${ }^{7}$ a certain moral high ground in international negotiations. However, for South Africa, these incentives are of particular importance to convince the international community of the country's commitment to continue with a non-weapons nuclear programme. To acquire and maintain a diplomatic niche requires recognition, and a secured position in a globally competitive arena requires publicity, including advocacy, positive branding, and the moral high ground. A major implication of a country's niche is that the country has some kind of advantage over other countries. ${ }^{8}$

\section{Niche diplomacy and multilateralism as diplomatic practices}

President Thabo Mbeki, as President Mandela's successor, contributed to an acceleration of South Africa's nuclear diplomacy. During Mbeki's presidential term (1999-2008), South Africa's commitment to nuclear nonproliferation was supplemented with normative innovation and norm internalisation. ${ }^{9}$ This period also saw increased South African support for Iran's nuclear programme, ${ }^{10}$ South Africa's participation in inspections of Iraq's nuclear facilities in February 2003, and increased South African exports of nuclear-related products. More importantly, the nuclear ambitions of the South African government became increasingly public. In 1999, for example, the South African government became one of the investors in the Pebble Bed Modular Reactor (PBMR) Company along with local and international investors. ${ }^{11}$

In contrast to this illustration of the country's commitment to nuclear non-proliferation during the tenure of President Mbeki was the involvement of South African citizens (but not the South African government) in the nuclear proliferation network of AQ Khan, which was confirmed and reported to the IAEA by South Africa's representative at the IAEA, Ambassador Abdul Minty. ${ }^{12}$ The Khan network also operated in Africa. Considered the 'father' of Pakistan's nuclear weapons programme, Khan's nuclear black market spanned the globe and involved actors from NWS and NNWS (non-nuclear-weapon 
states). This included illicit trade in nuclear equipment, expertise, goods, weapons and nuclear material by, amongst others, Iraq, North and South Korea, Libya, Dubai, Malaysia, Turkey, Spain, The Netherlands, Germany, Switzerland, the United Kingdom (UK) and Japan. The Khan network also operated in several African states, including Egypt, Mali, Mauritania, Sudan, Tunisia, Niger, Côte d'Ivoire, Nigeria and South Africa. ${ }^{13}$

South Africa has acted almost as a textbook example of middle-power behaviour in its practice of nuclear diplomacy. ${ }^{14}$ Middle-power behaviour is characterised by the form (either heroic or routine) of a state's behaviour. Firstly, South Africa has repeatedly displayed heroic behaviour (i.e. taking initiative) in its bridge-building, its problem-solving, and its sometimes confrontational behaviour to NWS and NNWS alike. Secondly, as a middle power, the scope of South Africa's activities pertaining to the country's nuclear diplomacy has consistently displayed discretion in negotiation fora by maintaining a consistent stance in compliance with the norms of the NPT. Thirdly, with regard to the focus and targets of South Africa's diplomatic activity, the country has consistently employed both multilateral (which here includes regional diplomacy) and bilateral diplomacy in the conduct of its nuclear diplomacy. Finally, a middle power's niche diplomacy is also characterised by the intensity of its diplomatic style. In carving its niche role in nuclear diplomacy and informed by its foreign policy and diplomatic practice, South Africa employed three strategies in its niche diplomacy:

- Confrontation: attempts to direct the terms of the current debate away from realism, irrespective of some form of ideological confrontation with the major NWS, such as the United States (US), the UK and France.

- Parallelism: attempts to cultivate a form of 'realism lite' or enlightenment through parallel action alongside the one superpower, namely, the United States (US) and its coalition partners.

- Partnership: engagement in active partnership with the dominant power, i.e. the US on a realistic footing. ${ }^{15}$

Typically, states practicing niche diplomacy focus on a specifically selected issue, organisation or activity. South Africa is no exception in this regard. The sources of South Africa's niche diplomacy in Africa are located in the tenets of middle-power diplomatic behaviour, which therefore provides a strong normative foundation and emphasises the country's entrepreneurial flair and technical expertise. Other key features of South Africa's niche diplomacy are the country's focus on consensus and coalition building in Africa, 
cooperation on nuclear issues, adopting the role of bridge builder (between Africa and the NWS), the country's role as mediator (between African states on the headquarters of the African Commission on Nuclear Energy [AFCONE]), its role as facilitator (of African gatherings on nuclear issues such as the Johannesburg meeting referred to earlier), or as catalyst (changing its nuclear posture) in African nuclear issues. The latter involved South Africa's planning, convening and hosting meetings, prioritising for future meetings on a particular issue and drawing up declarations and manifestos.

South Africa's practice of nuclear diplomacy cannot be divorced from its general practice of diplomacy as one of the instruments of the country's foreign policy. Consistent with its post-1994 foreign policy, the South African government has maintained its preference for multilateralism, focussing on Africa and the developing world, and maintaining the country's status as a good international citizen with regard to its nuclear diplomacy. An example of this is South Africa's involvement in the nuclear non-proliferation export control regimes. In Krasnerian terms, these regimes are a set of internationally accepted norms, laws, rules, principles and institutions which regulate the export, sharing and transfer of components, materials, services and technologies, which can be utilised for dual-use purposes, and thus prevent nuclear proliferation. ${ }^{16}$ Institutionally, these regimes consist of the Wassenaar Arrangement on Export Controls for Conventional Arms and Dual-Use Goods and Technologies (WA), the Missile Technology Control Regime (MTCR), the Nuclear Suppliers Group (NSG), and the Zangger Committee (ZC). South Africa is a member of all of these. As a former sanctions buster and illicit importer and exporter of nuclearrelated equipment, South Africa was determined to project itself as a rehabilitated nuclear state. Despite this, the South African government's efforts were undermined by a series of contentious nuclear proliferation-related incidents, most notably the AQ Khan network referred to earlier.

South Africa's membership of some of the above-mentioned regimes reflects the country's socialisation of the norms of non-proliferation, disarmament, and the peaceful uses of nuclear energy - more so as membership of these regimes is voluntary. Moreover, South Africa has incorporated aspects of this regime in its nuclear export trade policies and institutions such as the National Conventional Arms Control Committee (NCACC) and the South African Council for the Non-Proliferation of Weapons of Mass Destruction (NPC). With this, South Africa has, since 1990, constructed a state identity as a norm-compliant good international citizen. More importantly, in doing so, the country has enhanced its international influence, status and prestige. 
Post-apartheid South Africa's diplomatic relations with the IAEA and its members also reveal insights into the country's nuclear diplomacy after 1989. In constructivist terms, South Africa has not only constructed a new state identity and role, but it also constructed and advanced the country's national interests in its relations with the IAEA. South Africa's niche diplomacy in this case displays middle-power characteristics. The country was strengthened by its scientific and technical expertise in nuclear issues, which was advantageous to South Africa compared to other states. These advantages were locational, traditional and consensual. South Africa is the only African state to have acquired and given up its nuclear weapons (locational), the country has a nuclear history (traditional), and South Africa's non-proliferation commitment is reflective of the country's non-proliferation commitments after 1990 (consensual).

The Mbeki era also laid the foundation for South Africa's nuclear diplomacy with the rest of the African continent after 1990. South Africa acceded to the Pelindaba Treaty, which came into force on 15 July 2009. Since 1990, South Africa has conducted its diplomacy with African states in such a manner as to convince the continent of its commitment to the continent. The same applies to its nuclear diplomacy with Africa. By ascribing to the continental norm of a denuclearised Africa, South Africa constructed its identity accordingly to serve its national and international interests. For South Africa, this has not only created a practical reality (no more nuclear weapons), but it has also resulted in the normative reality of the country elected to the position of custodian of the Pelindaba Treaty by chairing the Treaty's instrument of compliance, namely the AFCONE. Characterised by a combination of normative innovation, norm maintenance, coalition building, confrontation, independence, partnerships and parallelism, South Africa's nuclear diplomacy with other African states has soon developed into a diplomatic niche for the country.

South Africa also attempted to undo existing global nuclear-related power structures by working towards a denuclearised African continent. In addition to this, South Africa's state identity as a domestic reformer proved to be a diplomatically useful identity to export to its diplomatic relations by advocating African and global reforms pertaining to the country's status as a denuclearised territory.

South Africa has attempted to construct a new conception of the country's foreign policy identity with the 'other' being its apartheid past, rather than another international actor. ${ }^{17}$ South Africa has also managed to construct a 
nuclear identity in Africa through 'positive approximation' by associating or identifying itself with the positive nuclear norms and identities of other African states. This nuclear identity has also been achieved through "negative approximation" by distancing the country from its historical nuclear actions, capabilities and posture. ${ }^{18}$

The implications of South Africa's nuclear diplomacy in Africa have been wide-ranging. Not only did it contribute to the coming into force of the Pelindaba Treaty but also to enhancing the country's status and prestige. South Africa, which no longer has nuclear weapons, continues to wield considerable soft or normative power on the African continent. ${ }^{19}$

South Africa's hosting and leadership of the AFCONE since November 2010 will test the country's normative power. Maintenance of the country's normative power pertaining to nuclear non-proliferation on the continent and elsewhere is dependent on the legitimacy of the country's nuclear diplomacy. This legitimacy, in turn, is dependent on the country's persuasive actions to promote nuclear non-proliferation on the continent and the AFCONE's activities.

\section{Power and nuclear diplomacy}

A significant implication of South Africa's nuclear diplomacy is that it is an instrument of the country's power, authority and influence. Before 1990, South Africa wielded some authority, influence and power due to the country's nuclear weapons capability. However, South Africa, which no longer has nuclear weapons, continues to wield considerable power, specifically soft or normative power. The country no longer conceptualises its power pertaining to nuclear matters in terms of that power's institutional and productive dimensions. Instead, a departure from power as resource to relational power reiterated South Africa's social rather than material construction of power. This is clearly evident in South Africa's construction of its power in the 1995 Review and Extension Conference (REC) and subsequent review conferences (RevCons) of the NPT.

The NPT, which came into force on 5 March 1970, rests on three major tenets, namely nuclear disarmament, nuclear non-proliferation, and the peaceful uses of nuclear energy. South Africa came full circle on the NPT. At first, as reluctant signatory of the NPT, South Africa has constructed its niche role in the NPT regime, and has repeatedly expressed its unequivocal support of the norms of the NPT. Since South Africa signed the NPT in 1991, it has actively 
participated in the Treaty's RevCons. South Africa's first attendance at these was in 1995 when the country attended the REC. The country's participation in and deadlock-breaking diplomatic efforts during the 1995 REC of the NPT have subsequently been hailed as a diplomatic success. At subsequent NPT conferences, South Africa achieved similar results. ${ }^{20}$ Whereas the country was historically accused of contravening the NPT since it came into force, it successfully constructed a niche role in the nuclear non-proliferation regime. Through the construction of new norms or through the entrenchment of existing norms, South Africa has crafted a unique brand of diplomacy and established a particular new state identity.

South Africa's soft and normative power in nuclear diplomacy is also evident in the various dimensions of power. ${ }^{21}$ Firstly, the scope of South Africa's power in nuclear diplomacy varies from one issue to another. With the establishment of the New Agenda Coalition (NAC) in 1998, South Africa flexed its muscle as part of a multilateral arrangement, whereas in the case of the 1995 REC, it acted alone. Domain (i.e. the number of actors under its influence) is another dimension of a state's power. ${ }^{22}$ Here, it refers to the number of actors under South Africa's influence in nuclear diplomacy. The domain of a state's power also implies that such country could have considerable influence in one area, and almost none in another. South Africa's influence in global nuclear affairs indicates the country's considerable influence in this area and over other actors compared to its influence in other domains. Weight as a dimension of a state's power determines the probability that the country's behaviour is or could be affected by one or more actors. South Africa's weight in nuclear matters has affected the nuclear-related behaviour of states which supported the country's position on the extension of the NPT. Means as a dimension of power refers to the ways a country exercises influence. These ways can be categorised as symbolic, economic, military and diplomatic. South Africa repeatedly employs its unique identity as a roll-back state (i.e. a state that has terminated its nuclear weapons capability) to symbolically flex its diplomatic muscles. Economically, South Africa expresses its power in nuclear diplomacy through its relative success related to the export regimes based on the country's production of, for example, medical isotopes. The country's non-use of its military power reinforces its power in nuclear diplomacy as South Africa opted to employ diplomacy, rather than military means, to enhance its nuclear interests.

Apart from understanding what 'power' and 'nuclear diplomacy' mean it is also instructive to determine what nuclear diplomacy does. Therefore, the performative aspects of nuclear diplomacy are equally important. The 
performative aspects of South Africa's nuclear diplomacy refer to what the country's nuclear diplomacy does, namely what is achieved (either materially or non-materially). This includes South Africa's official and voluntary representation at bi- and/or multilateral conferences, meetings and negotiations on nuclear-related issues. This is evident in South Africa's voluntary involvement in various organisations related to the nuclear non-proliferation export regime. It is also evident in the country's formal involvement in organisations such as the IAEA and the AFCONE. The second performative aspect of South Africa's nuclear diplomacy refers to the country's establishment and maintenance of nuclear-related relations with other states and multilateral organisations such as the AFCONE, the Non-Aligned Movement (NAM) and the IAEA. Thirdly, the performative aspects of South Africa's nuclear diplomacy include the initiation and maintenance of ideas relating to the peaceful uses of nuclear technology. This is particularly evident in South Africa's advocacy of all states' inalienable right, especially in terms of the NPT and the Pelindaba Treaty, to use nuclear energy for peaceful purposes. ${ }^{23}$ A final performative aspect of South Africa's nuclear diplomacy refers to the country's norm entrepreneurship and the socialisation of non-proliferation norms in order to entrench nuclear-related norms in international relations. This is closely related to the country's intersubjective understandings of the nuclear taboo and the peaceful uses of nuclear power.

\section{Construction of norms, identity and interests}

The skilful construction of South Africa's post-1990 nuclear identity and interests coincided with the country's norm entrepreneurship and its socialisation of nuclear non-proliferation norms. The political process whereby South Africa was socialised into norm construction, enactment and compliance on nuclear non-proliferation norms corresponds with socialisation processes associated with the three stages of the life-cycle of norms. ${ }^{24}$ The first stage in this cycle entailed the emergence of a norm through the initiative of norm entrepreneurs in governments that call attention to a particular issue. In the case of post-1990 South Africa, this role was played by Presidents De Klerk, Mandela and Mbeki, and South African diplomats, most notably Abdul Minty. South Africa's socialisation process relating to the norm of nuclear non-proliferation included interactions with like-minded states and multilateral organisations and the country's interpretation and internalisation of the meaning of norms such as nuclear non-proliferation, nuclear disarmament and the peaceful uses of nuclear energy. ${ }^{25}$ The second stage in this cycle involved norm cascade. This occurred when South Africa attempted to publicise the need for the entrenchment of a 
norm by socialising with governments and organisations. The final stage involved the internalisation of the norm of nuclear non-proliferation, an issue which manifested in the country's legislation and non-proliferation institutions.

Therefore, South Africa's compliance with nuclear non-proliferation norms provided for the standard(s) for the country's appropriate behaviour as a nuclear roll-back state with a given identity. South Africa's norm compliance in ordering, prescribing and regulating its diplomatic action on nuclear matters enabled the country's diplomatic interactions with other actors. Nuclear nonproliferation norms were constitutive as they provided South Africa with an understanding of its own mutual or individual interests - as well as those of other states - that could affect South Africa's diplomatic stance and/or behaviour on a particular nuclear-related issue.

South Africa's repeated support of nuclear non-proliferation norms played a constitutive role in the formation of the country's nuclear-related identities and interests. South Africa's consistent voluntary compliance with international law and adherence to settled norms on nuclear non-proliferation, nuclear disarmament and the peaceful uses of nuclear energy contributed to the country's predictability, trustworthiness, credibility, status and prestige. South Africa's voluntary membership of organisations and initiatives such as the NSG, the WA and the ZC serves the country's long-term interests as it derives benefits from the stability and predictability of the international order. Therefore, the logic of South Africa's nuclear diplomacy is to comply with settled norms on the use of nuclear power.

South Africa's norm compliance rests on at least two considerations. Firstly, norms express the dominant ideas of society. Non-compliance may result in detrimental sanctions and therefore actors comply in order to avoid such actions. Secondly, compliance with norms may be beneficial to an actor's national interests. ${ }^{26}$

All states strive to achieve and advance four national interests, namely physical survival, autonomy, economic well-being and collective self-esteem. South Africa is no exception in this regard. In its conduct of nuclear diplomacy, it strives to advance these interests which emanate from its identity. This contribution followed the typology of state identities put forward by Alexander Wendt. ${ }^{27}$ A state's identity performs various functions: it indicates 'who' a state is, it is the driving force behind a state's foreign policy, it indicates what motivates a state, and explains its intentions and interactions. More importantly, 
a state's identity ensures predictable patterns of behaviour. When applied to South Africa's conduct of nuclear diplomacy, the country's identity included multiple state identities.

South Africa's personal or corporate identity was revealed as constituted by the self-organising structures (norms, beliefs and resources) that make the country a distinct political entity that advances its national interests. This identity is particularly evident in South Africa's construction of internal selforganising structures to comply with norms on the use of nuclear energy and the nuclear non-proliferation export control regime. Another significant aspect of South Africa's corporate identity refers to the international recognition the country received since 1990 for its nuclear roll-back. In various diplomatic arenas, such as its bi- and multilateral relations, South Africa's role was recognised. South Africa's nuclear roll-back and the country's proposals for the 1995 REC and subsequent NPT conferences are only two of several examples of international recognition. South Africa's type identity refers to the country's commonly shared characteristics with other states. Its type identity was clearly evident in South Africa's membership of nuclear non-proliferation organisations such as the NAC, the NSG, the WA and the ZC.

Its type identity also refers to the historical commonalities South Africa shares with other states such as members of the Non-Aligned Movement (NAM) and other African states. More importantly, South Africa's type identity also includes the country's identity as one of the few states which historically had a nuclear weapons programme, but had dismantled it. Another type is South Africa's social identity, which consists of a set of meanings it attributed to itself. This identity refers to South Africa's identity of the 'self' relative to the 'other'. This type of state identity is clearly evident in the country's social identity in its reference to its unique identity as a country which terminated its nuclear weapons programme compared to other states that continue with theirs. Moreover, in terms of its nuclear diplomacy, the construction of South Africa's post-1990 social identity revolved around the country's identity as a state that has socialised nuclear non-proliferation norms indicative of the country's departure from a country with nuclear weapons to a completely nuclear disarmed state. South Africa has repeatedly referred to its self-image in this regard. The country's identification with the 'other' is another aspect of its social identity. Since 1990, South Africa has identified itself not only with roll-back states, but also with the position of NWS and developing countries on the right to develop nuclear energy for peaceful purposes. This identification is evident in South Africa's support for the NAM and the NAC at NPT RevCons. ${ }^{28}$ 
South Africa's construction of a niche role in nuclear diplomacy evolved from the deliberate attempts by foreign policy decision-makers of the NP-led government, the subsequent GNU and the ANC-led government. South Africa's niche role resulted in policy makers' own definition or role conception of the country's obligations towards external actors and these actors' expectations of South Africa (role prescription). South Africa's ascribed and prescribed roles in its nuclear diplomacy are clearly evident. The country's return to the IAEA Board of Governors in 1995 is one example as is the country's accession to the NPT and the Pelindaba Treaty.

Employing several strategies by focussing on the specific area of nuclear issues, South Africa has employed its expertise pertaining to nuclear issues to carve a middle-power role. The country's ability to initiate proposals to prevent deadlocks, such as the deadlock that occurred at the 1995 REC and South Africa's participation in such initiatives as the nuclear non-proliferation export regimes and the NAC also reflected the country's middle-power identity. ${ }^{29}$

For South Africa, an important function of its newly constructed state identities is often imposed or self-imposed international leadership. This is clearly evident in the country's nuclear diplomacy. South Africa served in various leadership positions, hosted international nuclear-related meetings, proposed solutions at conferences and is a voluntary member of various export regimes. Moreover, this is also clearly evident in the country's preference for multilateralism as a form of global interaction.

In its practice of niche diplomacy, South Africa employed a number of diplomatic practices, which provided some material and non-material rewards such as status, prestige and trade opportunities. Employing confrontation as a diplomatic strategy, South Africa often confronted NWS such as the US, the UK, China, Russia and France. This has been the case at various NPT conferences.

South Africa's employment of parallelism as a diplomatic strategy is illustrated in the country's parallel diplomatic actions alongside superpowers and their coalition partners. This was the case in South Africa's involvement in the NAC at the NPT RevCons. However, South Africa predominantly preferred partnership and cooperation as the country's preferred diplomatic strategies. 
Closely related to its leadership role is South Africa's social identity as an accommodator, mediator or bridge builder in nuclear matters. This is evident in the country's involvement in various NPT conferences and at the IAEA where the country often articulates and advances the interests of NNWS and developing countries.

The third type of South Africa's state identity refers to the country's collective identity. This identity is constructed when a state's social identity generates collective interests. Expressions of solidarity, community and loyalty emerge from these collective interests. South Africa's collective identity is a combination of role and type identities to overcome collective action problems (such as nuclear proliferation) as defined by international actors. This identity merged the previous types of identity in order to establish a single identity. This is clearly evident in South Africa's nuclear diplomacy with African states in the context of the Pelindaba Treaty.

\section{The future of South Africa's nuclear diplomacy}

Notwithstanding these successes, several nuclear-related issues remain a concern, are still unresolved or took a long time to resolve. Despite several appeals by the IAEA, the protracted process of converting the country's nuclear research reactor - the South African Fundamental Atomic Research Installation (SAFARI-1) - from operating with weapons grade HEU to operating with lowenriched uranium (LEU) was only completed by mid-2009. Issues pertaining to the safety of radioactive waste and the security of nuclear installations, such as Pelindaba, the headquarters of the Nuclear Energy Corporation of South Africa (NECSA), have been raised repeatedly. The admission by Pakistan's leading nuclear official, AQ Khan, of the involvement of South African citizens in a global nuclear black market was a cause of considerable diplomatic embarrassment, which compromised the country's non-proliferation image. ${ }^{30}$ Despite the sentencing of two individuals involved, several other individuals (i.e. South Africa and non-South African citizens) were not brought to book. ${ }^{31}$

The most pertinent question relating to a roll-back state is the possibility that a state would return to developing its nuclear weapons capability. South Africa constructed its roll-back credentials over two decades. Despite this, these efforts were undermined by several events. Firstly, the IAEA's initial verification was incomplete, which resulted in questions on South Africa's commitment to nuclear non-proliferation and disarmament. Once the verification was completed in 1993, the country's credentials were accepted. 
Secondly, South Africans' involvement in the Khan network also undermined the country's status and prestige as a roll-back state. Moreover, as a voluntary member of various nuclear non-proliferation export regimes, the involvement of South Africans raised concerns over the possibility of other similar instances.

In the third instance, South Africa is blatantly ambitious to carve a unique position in the global nuclear arena. This was clearly illustrated in the country's campaign for Abdul Minty's election as the IAEA director general. However, South Africa underestimated the interests of the NWS, who went ahead to appoint a Japanese director general, a citizen from the only country to have suffered the devastation of atomic bombs.

Irrespective of its non-proliferation stance, the South African government remains committed to an ambitious nuclear agenda. Whilst maintaining its status as a member of a unique nuclear non-proliferation club, the country set its sights on the construction of a PBMR (subsequently terminated in 2010), on enriching and recycling uranium, and on improving its share in the global medical isotope market. In February 2003, a few weeks prior to the US-led Coalition of the Willing invasion of Iraq, South African President Thabo Mbeki announced the impending departure of a team of South African disarmament experts to Iraq following Iraqi President Saddam Hussein's acceptance of South Africa's offer to send an envoy to the country to "share with their government, scientists, engineers, technicians and people of Iraq its experience relevant to the mission of the United Nations and Iraq to eradicate weapons of mass destruction, under international supervision". ${ }^{32}$ Mbeki maintained that this intervention would "help to ensure the necessary proper cooperation between the United Nations inspectors and Iraq, so that the issue of weapons of mass destruction is addressed satisfactorily, without resorting to war". 33

The South African government also expressed its intention to develop the country's nuclear industry in its National Nuclear Energy Policy (2008) and in its Ten-Year Plan for Science and Technology (2007). ${ }^{34}$ In 2008, the Minister for Minerals and Energy stated that the National Nuclear Energy Policy "represents the Government's vision for the development of an extensive nuclear energy programme" in order to develop a national nuclear architectural capability to "supply nuclear equipment and nuclear reactors" as well as the 
"ability to design, manufacture, and market, commercialise, sell and export nuclear energy systems and services". ${ }^{35}$

In the fourth place, South Africa's nuclear intentions remain in question, especially against the background of the South African government's declaration that it is a responsible producer, possessor and trader of nuclear expertise, products and services. In April 2011, the South African government adopted the Integrated Resources Plan (IRP), which paved the way for the expansion of the country's nuclear power generation capacity. South Africa's Minister of Energy confirmed that "nuclear and renewable energy will have a significant contribution" to the country's future energy supply. ${ }^{36}$ Subsequent to this decision, the South African cabinet approved the establishment of the National Nuclear Energy Executive Coordination Committee (NNEECC) and its Nuclear Energy Technical Committee (NETC) to "implement a phased decision making approach to the nuclear programme". ${ }^{37}$

Finally, South Africa's nuclear intentions are also questioned due to the announcement by the Minister of State Security in 2011. Referring to the country's forthcoming National Security Strategy, he alluded to the country's nuclear future by stating that his government has identified dual-use technologies as involving "major aspects of our country's competitiveness and innovative capacity for commercial market access and national security". ${ }^{38} \mathrm{He}$ also announced that an inter-departmental task team was conducting an "assessment of resources and activities of the peaceful programs related to the field of nuclear, biological, chemical, aerospace and missile technologies". He further announced that the task team would develop a national strategy to promote research, technological development, innovation, coordination, integration and oversight in the field of these dual-use technologies in South Africa. These developments will undoubtedly influence South Africa's future nuclear diplomacy.

\section{Conclusion}

Constructivist ontology engages with three main components, namely inter-subjectivity, context and power. With regard to intersubjectivity, the article emphasised the interactions between nuclear-related structures and agents. Agents' intersubjective understandings of the norms of nuclear nonproliferation, nuclear disarmament, and the peaceful uses of nuclear energy constructed identities, interests, role and meanings, and vice versa. This resulted in the mutual constitution of agents and structures and explains the descriptive 
narrative presented here as narratives highlight the agency of states. For constructivists, once these intersubjective understandings and meanings manifest in settled norms, institutions or structures are established. South Africa's intersubjective understanding of the settled norms mentioned earlier contributed to the country's decision to comply with these norms and accede to the Pelindaba Treaty and the NPT.

Context is another ontological dimension of constructivism. South Africa's nuclear diplomacy is contextually linked to the Cold War (historical context), the nuclear arms race (social context), the country's domestic policies (social context), and the country's regional threat perception (spatial context). Developing nuclear weapons for deterrence, South Africa's nuclear diplomacy is linked with this past and the country's future to undo this legacy as its context changes.

The third dimension of constructivists' ontology is power. For decades, one of the dominant intersubjective understandings of South Africa was that it has been a country with a nuclear weapons capability and internationally unacceptable policies that violated the human rights of the majority of South Africans. South Africa derived its power from a material, rather than an immaterial, base. Once the country had terminated its nuclear weapons programme, acceded to the NPT and had successfully undergone the IAEA verification process, it was able to construct a new identity due to the changed nature of its interests. This newly won identity as a roll-back state reversed the dominant intersubjective understanding of South Africa and bestowed the country with significant normative power.

Constructivists share the notion of the mutual constitution of reality. This undermines the notion of objective facts as intersubjective understandings that constitute these facts. Therefore, constructivists maintain that what is defined as 'facts' and 'reality' is subjectively rather than objectively constructed. Therefore, norms as 'social facts' are mutually constituted based on intersubjective understandings.

South Africa's niche role and state identity in nuclear diplomacy can be interpreted in several ways. Knowledge about South Africa's nuclear past only became known with President De Klerk's 1993 announcement. The South African government, which denied the existence of its nuclear weapons programme prior to 1989, constructed a regime of truth (i.e. knowledge in service of power) to support this. Similarly, the ANC-led government 
constructed a comparable regime of truth, now to perpetuate its stance on nuclear non-proliferation, nuclear disarmament and the peaceful uses of nuclear energy.

Several epistemological contributions have been made in this article. These contributions provide insight into state behaviour relating to a state's decision to terminate its nuclear weapons programme and its reconstruction of identity, power and interests in the absence of these instruments of power. The article also contributes to insight regarding nuclear diplomacy as a particular diplomatic practice emanating from a state's foreign policy. In addition to this, the findings from the study contribute to an understanding of middle-power behaviour as it relates to a middle power from the developing world.

Only a small number of countries have completely terminated their nuclear weapons programmes. These countries include Brazil, South Africa and Libya, all developing countries and NNWS. Their commitment to the norms of nuclear disarmament, nuclear non-proliferation and the peaceful uses of nuclear energy signifies normative entrepreneurship by middle to small powers. Moreover, it also refers to the role of regional powers in regional and international security.

\section{Endnotes}

${ }^{1}$ De Klerk, FW. "Matters relating to nuclear non-proliferation treaty, violence, negotiation and the death penalty. Statement by the State President to a Joint Sitting of Parliament”, Hansard. 24 March 1993. Columns 3465-3478; Stumpf, W. "Birth and death of the South African nuclear weapons programme". Paper presented at the 50 Years after Hiroshima conference, Castiglioncello, 28 September $\quad-\quad 2$ October 1995. <http://www.fas.org/nuke/guide/rsa/nuke/stumpf.htm> Accessed on 12 May 2014..

2 Wendt, A. "Anarchy is what states make of it: The social construction of power politics". International Organization 46/2. 1992. 391-425; Wendt, A. Social theory of international politics. Cambridge: Cambridge University Press, 1999.

${ }^{3}$ Department of Foreign Affairs. "Multilateral". 2009. <http://www.dfa.gov.za/foreign/Multilateral/inter/treaties/> Accessed on 9

${ }^{4}$ Ibid. April 2009 
5 Van Wyk, J. "Nuclear diplomacy as niche diplomacy: South Africa's postapartheid relations with the International Atomic Energy Agency". South African Journal of International Affairs 19/2. 2012. 179-200.

${ }^{6}$ Henrikson, AK. "Niche diplomacy in the world public arena: The global 'corners' of Canada and Norway". In Melissen, J (ed), The new public diplomacy: Soft power in international relations, New York: Palgrave Macmillan, 2005, 67.

7 Geldenhuys, D. "South Africa's role as international norm entrepreneur". In Carlsnaes, W \& Nel, P (eds), In full flight: South Africa's foreign policy since apartheid, Midrand: Institute for Global Dialogue, 2006, 93-96.

${ }^{8}$ Henrikson op. cit., pp. 70-72.

${ }^{9}$ Geldenhuys op. cit., pp. 93-96.

${ }^{10}$ Pahad, A. "A balance of rights and obligations: Understanding the issue of nuclear energy in Iran". Umrabulo 26/2. 2006. 1-45.

${ }^{11}$ Fig, D. Nuclear energy rethink? The rise and fall of South Africa's pebble bed modular reactor. Institute for Security Studies (hereafter ISS) paper 210. Pretoria: ISS, 2010.

${ }^{12}$ Minty, A. "Statement by South Africa at the IAEA Board: Update on the illicit network". Vienna, $11 \quad$ September 2007. <http://www.dirco.gov.za/docs/speeches/2007/mint0911.htm> Accessed on 12 May 2014.

13 International Institute for Strategic Studies (hereafter IISS). Nuclear black markets: Pakistan, AQ Khan and the rise of proliferation networks. A net assessment. London: IISS, 2007.

${ }^{14}$ Cooper, AF (ed). Niche diplomacy: Middle powers after the Cold War. London: Macmillan, 1997.

${ }^{15}$ Henrikson op. cit., p. 74.

${ }^{16}$ Krasner, SD. International regimes. Ithaca: Cornell University Press, 1983.

17 Serrão, O \& Bischoff, P. "Foreign policy ambiguity on the part of an emergent middle power: South African foreign policy through other lenses". Politikon 36/3. 2009. 363-380.

18 Ibid.

${ }^{19}$ Nye, J. The paradox of American power: Why the world's only superpower can't go it alone. Oxford: Oxford University Press, 2002.

20 Taylor, I. "South Africa and the Nuclear Non-Proliferation Treaty". In Lee, D, Taylor, I \& Williams, PD (eds), The new multilateralism in South Africa's diplomacy, New York: Palgrave Macmillan, 2006.

${ }^{21}$ Baldwin, DA. "Power and international relations". In Carlsnaes, W, Risse, T \& Simmons, BA (eds), Handbook of international relations, London: Sage, 2002, 178-179.

${ }^{22}$ Ibid.

${ }^{23}$ Minty, A. "Speech delivered by Ambassador AS Minty at the first session of Preparatory Committee for the 2010 Review Conference of the Parties to the 
Treaty on the Non-Proliferation of Nuclear Weapons”. Vienna, 1 May 2007. < http://www.dfa.gov.za/docs/2007/npnw0501.htm> Accessed on 12 May 2014.

${ }^{24}$ Finnemore, M \& Sikkink, K. "International norm dynamics and political change". International Organization 52. 1998. 894-905.

25 Koh, HH. "Why do nations obey international law?" Yale Law Journal 106/8. 1997. 2598-2599.

26 Armstrong, D, Farrel, T \& Lambert, H. International law and international relations. Cambridge: Cambridge University Press, 2007, 97.

${ }^{27}$ Wendt op. cit., pp. 391-425.

${ }^{28}$ Van Wyk, JK. "South Africa's nuclear diplomacy, 1990-2010: Securing a niche role through norm construction and state identity". DPhil thesis. University of Pretoria, 2013.

${ }^{29}$ Masiza, Z \& Landsberg, C. "Fission for compliments? South Africa and the 1995 extension of the Nuclear Non-Proliferation Treaty". Policy: Issues and Actors 9/3. 1996. 31.

${ }^{30}$ IISS op. cit.

31 National Prosecuting Authority (hereafter NPA). "S v Gerhard Wisser". 4 September <http://www.npa.gov.za/UploadedFiles/S\%20v\%20Gerhard\%20Wisser_\%2 004\%20September\%202007.pdf> Accessed on 12 May 2014; NPA. "S v Geiges. Annexure to the Plea and Sentence Agreement". February 2008. <http://www.npa.gov.za/UploadedFiles/GEIGES\%20Annexure\%20to\%20P1 ea\%20agreement\%2016\%201\%2008\%20_2_.pdf> Accessed on 12 May 2014.

32 Government Communication and Information Service. "SA disarmament experts arrive in Iraq" BuaNews. 24 February 2003. <http://ww.buanews.gov.za> Accessed on 8 October 2009.

33 "Mbeki picks experts to assist Iraq in weapons destruction" Panapress, 19 February 2003. <http://www.panapress.com/Mbeki-picks-experts-to-assistiraq-in-weapons-destruction--13-473044-18-lang1-index.html>. Accessed on 12 May 2014.

${ }^{34}$ Department of Minerals and Energy. "Nuclear energy policy for the Republic of South Africa". 2008. <http://www.dme.gov.za> Accessed on 8 April 2009 Department of Science and Technology of South Africa. "Ten year plan for science and technology, 2008-2018”. 2007. <http://www.artsci.wustl.edu/ anthro/courses/306/Sarah\%20Burial.html> Accessed on 14 April 2009.

${ }^{35}$ Department of Minerals and Energy, op cit., p 4.

${ }^{36}$ Peters, D. "Opening remarks by the Minister of Energy". Paper presented at the $2^{\text {nd }}$ Regional Conference on Energy and Nuclear Power in Africa, Cape 
Town, 30-31 May 2011. <http://www.energy.gov.za> Accessed on 14 November 2011.

${ }^{37}$ Government Communications and Information Service (GCIS). "Statement on the Cabinet meeting of 9 November 2011". 10 November 2011. < http://www.gcis.gov.za/content/newsroom/media-releases/cabinetstatements/statement-cabinet-meeting-9-november-2011> Accessed on 12 May 2014.

${ }^{38}$ Cwele, S. "Address by the Minister of State Security". State Security Budget Vote, Parliament, Cape Town. 2 June 2011. <http://www.ssa.gov.za/Speeches/2011/Minister_Budget\%20Vote\%202011 \%20Revised.pdf $>$ Accessed on 13 February 2012. 